\title{
ECOLOGICAL FEATURES AND SYNANTHROPIZATION OF BRYOFLORA IN THE POHULYANKA FOREST PARK (LVIV CITY, UKRAINE)
}

\author{
Zvenyslava MAMCHUR, Yuriy DRACH, Halyna ANTONYAK \\ Department of Ecology, Ivan Franko National University of Lviv, Saksaganski Str. 1, 79005 Lviv, Ukraine \\ e-mail: dzvinkamamchur@gmail.com, yuradrach91@gmail.com, halyna_antonyak@gmail.com
}

\begin{abstract}
This paper analyses ecological features of bryophyte species from the territory of the Pohulyanka Forest Park in the city of Lviv, Ukraine. A total of 141 species of bryoflora were analyzed (70 recorded for the first time). In the spectrum of life forms (LF), species with the following LF prevailed in the study area: turf (61 species, 43.3\%), mat (48 species, 34\%). Turf, the most common life form, was detected on all types of substrates, but was most frequently found on the soil (33 species, $23.4 \%$ ) and stony substrates (13 species, $9.2 \%$ ). Analysis of herbarium specimens (herbariums of Ivan Franko National University of Lviv, National Museum of Natural History of the National Academy of Sciences of Ukraine, and the Institute of Ecology of the Carpathians of the National Academy of Sciences of Ukraine) and the results obtained with respect to the composition of the bryoflora suggest that since the mid-19th century, due to anthropogenic transformation of the study area, most species with LF weft (10 out of 15 species, or 66.7\%) have disappeared, while the number of species with LF rough mat on the soil has increased. The apophytic fraction of bryoflora in the study area consists of 121 species (85.8\%) belonging to 28 families and 66 genera, including four species in the division Marchantiophyta. In the composition of bryophyte flora, 67 species of eventapophytes were identified (47.5\% of the total number of species). Dominant families are Brachytheciaceae, Mniaceae, Pottiaceae, Plagiotheciaceae, Orthotrichaceae, Polytrichaceae. Hemiapophytes comprised 24.1\% (i.e. 34 species) of the total number of species. The largest number of hemiapophytes was found in the families Pottiaceae, Bryaceae, Amblystegiaceae and Orthotrichaceae. Among the spontaneophytes (20 species, 14.2\%), the families Hypnaceae, Mniaceae and Polytrichaceae prevailed. Indigenophytes amounted to 20 species (14.2\%). With regard to the relationship of bryophytes to light, the following groups were identified in the study area: ultraheliophytes, heliophytes, subheliophytes, hemisciophytes and sciophytes. The highest number of species was represented by subheliophytes and hemiscyophytes. Certain patterns were found in the ratio of sun-demanding species in groups of apophytes. Among the hydromorphs, the following groups were identified: ultraxerophytes (found only among hemiapophytes); xerophytes (prevailing in the group of hemiapophytes, but also found among eventapophytes); xeromesophytes, mesophytes, hygromesophytes and hygrophytes (represented in all anthropotolerant groups); hydrophytes (event- and spontan/indigenophytes).
\end{abstract}

Keywords: bryoflora, life forms, ecomorphs, synanthropization, Pohulyanka Forest Park, Lviv urban ecosystem.

\section{Introduction}

Bryophytes are an important component of terrestrial and aquatic biota, and the changes that occur to bryoflora in urban ecosystems under the influence of various anthropogenic factors have long attracted the attention of bryologists $[1,2,6,10-19,21,23,39$, 42, 46-48, 51-53, 57, 58]. The main environmental factors in cities are significantly different from those that influence plants in natural conditions. These are, in particular, higher temperature and severe dryness of air 
and soil, vehicle emissions, adverse soil conditions (mechanical compaction, pollution with household and construction waste, sand and salt accumulation after anti-icing treatment, freezing, etc.). The high content of dust and gases in the urban atmosphere contributes to the accumulation of heat and causes the formation of 'hot islands'. The groundwater level decreases and the soil itself becomes dry, compacted and polluted [49].

The city of Lviv is one of the most industrially developed centres of Western Ukraine. The city centre is characterized by high building density; by contrast, there are many green areas in the city as well as in suburban areas. However, over the past decades these areas have undergone significant transformations of terrestrial vegetation, including changes in the composition of the bryoflora, as a result of exposure to various types of anthropogenic pressure. A high degree of anthropogenic transformation of plant cover is associated with longstanding economic activity, with a significant density of residential areas, the presence of many transport routes, the replacement of tall woody vegetation by low vegetation, as well as by weed vegetation, both segetal and ruderal [20, 28-30].

Pohulyanka Forest Park and the adjacent territory of the Botanical Garden of Ivan Franko National University of Lviv are located in the south-eastern part of the city, relatively close to the centre and one of the recreational parts of Lviv. The territory of Pohulyanka is characterized by significant anthropogenic changes and recreational loads, but at the same time natural and seminatural ecotopes have been preserved: wetlands near the springs and reservoirs, ravine slopes, which are subjected to significantly lower recreational loads, etc. During the last century, the territory of the Pohulyanka Forest Park often underwent significant changes: 1) until 1940; 2) the period of the Second World War, the post-war period and the years of fundamental reconstruction (1941-1990); 3) the modern period (1991-2018).

The territory of the Pohulyanka Forest Park is characterized by significant bryofloristic diversity. In the previous study, based on the results of our research, analysis of herbarium specimens and literature data on the species composition of bryophytes in the territory of Pohulyanka, we identified features of the anthropogenic transformation of bryoflora that occurred during the last 50-100 years [33]. The purpose of this study was to investigate the ecological features of bryophytes and their life forms, as well as to clarify the processes of synanthropization of the bryoflora in the Pohulyanka Forest Park in the territory of the city of Lviv.

\section{Materials and Methods}

\section{Study area}

The city of Lviv $\left(49^{\circ} 83^{\prime}-49^{\circ} 50^{\prime} \mathrm{N}, 24^{\circ} 00^{\prime}-24^{\circ} 10^{\prime} \mathrm{E}, 320-382 \mathrm{~m}\right.$ a.s.1) is situated in Western Ukraine and covers an area of $182 \mathrm{~km}^{2}$ with approximately 730,270 inhabitants. Lviv is situated at the intersection of four physiographic regions: Davydiv Plateau, Lviv Plateau, Ukrainian Roztocze, and Ridged Pobuzhya [44]. Within the territory of Lviv, Pohulyanka Forest Park and Botanical Garden of Ivan Franko National University were examined to study the life forms and ecological features of bryophytes (Fig. 1).

Pohulyanka Forest Park $\left(49^{\circ} 49^{\prime} 24^{\prime \prime} \mathrm{N}, 24^{\circ} 04^{\prime} 00^{\prime \prime} \mathrm{E}\right)$ is located in the south-eastern part of the city on the elevation of the Davydiv Ridge. It has been opened as a municipal park in the first half of the 19th century and now belongs to the monuments of landscape art of regional importance. The Botanical Garden of Ivan Franko National University of Lviv occupies territory 
adjacent to the Pohulyanka Forest Park. It was created in 1911 in the place of the former Cetnerivka ornamental garden on a complex relief.

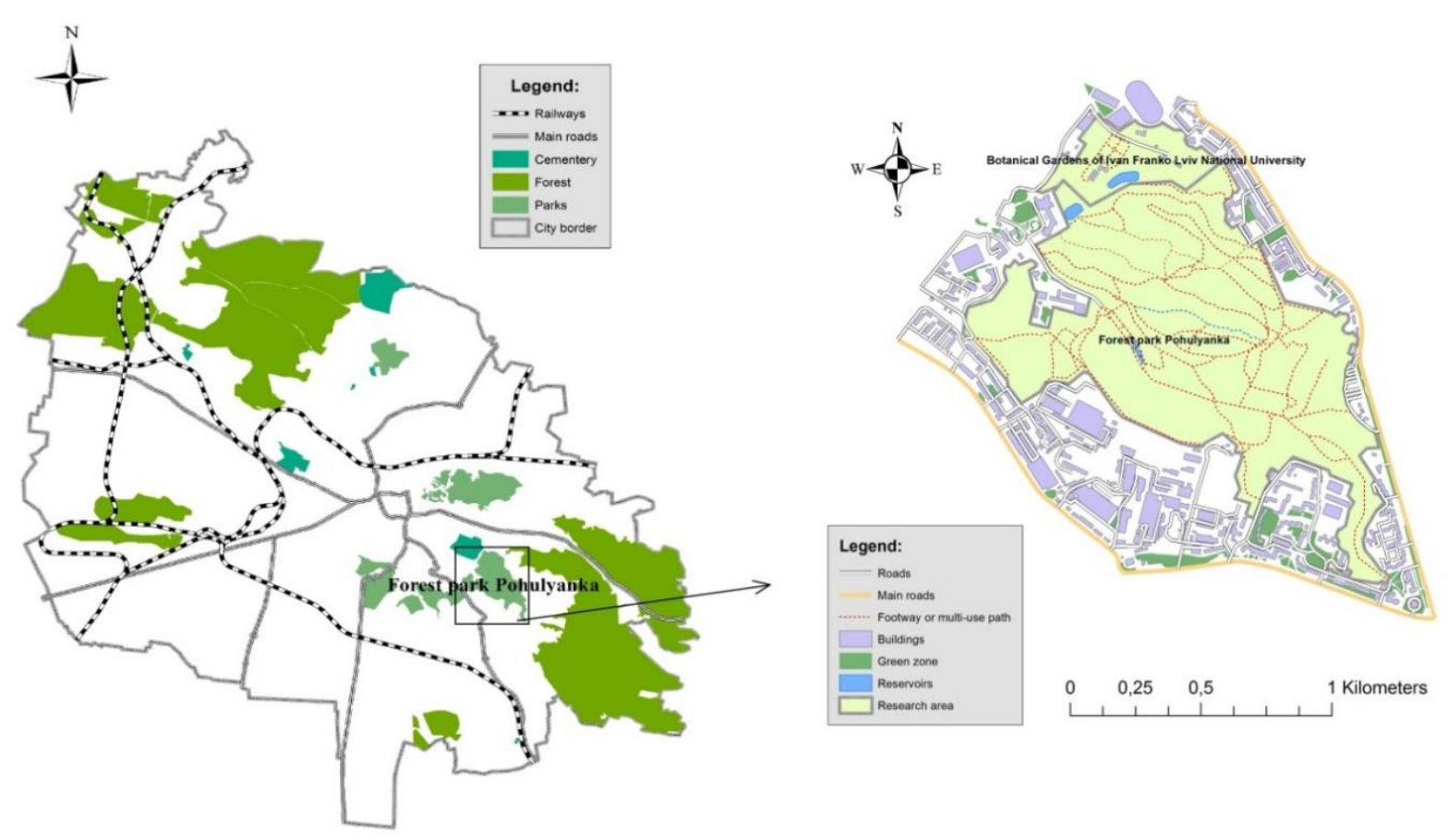

Fig. 1: Maps of the city of Lviv and Pohulyanka Forest Park $\left(49^{\circ} 49^{\prime} 24^{\prime \prime} \mathrm{N}, 2^{\circ} 04^{\prime} 00^{\prime \prime} \mathrm{E}\right)$.

\section{Data collection}

Field studies were conducted using standard methods during the vegetation period of 20142018 in different seasons. The collection of moss material and the identification of bryoflora species were carried out according to generally accepted methods. Latin taxon names were used in accordance with the nomenclature developed by M. Boiko [5]. Data on the species composition and taxonomic analysis of the bryoflora of the Pohulyanka Forest Park, were presented in our previous work [33].

The classification proposed by M.O. Hill et al. [22] was used to identify the life forms (LF) of bryophytes. Among the bryophytes whose shoots were not part of an organized colony, three different LFs were identified: solitary creeping (Sc), turf protonemal (Tp), and turf scattered (Ts). Most bryophyte species are characterized by clonal or colonial life forms. Among these species, we have determined the following LFs: turf (Tf), tuft (Tuft), cushion $(\mathrm{Cu})$, dendroid (De), mat rough $(\mathrm{Mr})$, mat smooth $(\mathrm{Ms})$, mat thalloid $(\mathrm{Mt})$, weft (We), and fan $(\mathrm{Fa})$.

The synanthropic fraction of bryoflora was identified according to the generally accepted classification by J.A. Kornaś [24] with additions done by V. Protopopova [40] and Ya. Didukh et al. [8], using the analysis of the synanthropic bryoflora of Ukraine performed by M. Boiko [4], and data from studies conducted by O. Maslowsky [37] and R. Ochyra [38].

Ecological groups of bryophytes in relation to light and moisture were determined on the basis of own observations using the values of the Ellenberg indicators elaborated by R. Düll [9], M. O. Hill et al. [22], and K. Dierßen [7]. 


\section{Results}

Studies of the bryoflora of Lviv and its surroundings have been conducted since the middle of the 19th century. The oldest data refer to the publications of H. Łobarzewski $(1847,1849)$, I. Czerkawski (1868) and I. Krupa (1885). In the first half of the 20th century, studies were continued by F. Lilienfeldówna (1910, 1911, 1914), A. Żmuda (1911, 1912) and T. Wisniewski [28]. However, data on the composition of bryoflora in the territory of the Pohulyanka Forest Park is limited; currently, most of the information is available mainly from herbarium material. The bryological collections gathered by H. Drozdowska (1939) and stored in the Herbarium of Ivan Franko National University of Lviv (LW) remain unpublished. The herbariums of the National Museum of Natural History of the National Academy of Sciences of Ukraine (LWS) and the Institute of Ecology of the Carpathians of the National Academy of Sciences of Ukraine (LWKS) possess moss material from the second half of the 20th century (collected by A. Lazarenko, K. Ulychna, M. Slobodian, O. Vysotska, E. Lesniak) and modern collections (I. Danylkiv, Z. Mamchur, M. Rahulina, Yu. Drach) [33].

A complete list of bryophytes from the Pohulyanka Forest Park, based on our research, herbarium materials (LW, LWS, LWKS) and literature data [25-26, 43], consists of 141 species in two divisions (Marchantiophyta, Bryophyta), 36 families and 79 genera. Of these, 70 species were first records for the study area [33].

In the study area, 12 types of bryophyte LF were identified, with a prevalence of those that form an organized colony. Among them, the dominant position is occupied by species whose LF is turf (61 species, $43.3 \%)$ : $\mathrm{Tf}-42$ species $(29.9 \%)$, Tuft -15 species $(10.6 \%)$ and $\mathrm{Ts}-4$ species (2.8\%). The second place is occupied by LF mat (48 species, 34\%): Mr - 27 species (19.2\%), Ms -17 species $(12 \%), \mathrm{Mt}-4$ species $(2.8 \%)$, and the third most common LF is weft (15 species, $10.6 \%)$. Cushion is characteristic of 13 species (9.2\%), Sc -1 species (0.7\%) (Fig. 2). For the last period, no species with life forms of Tp and De were found.

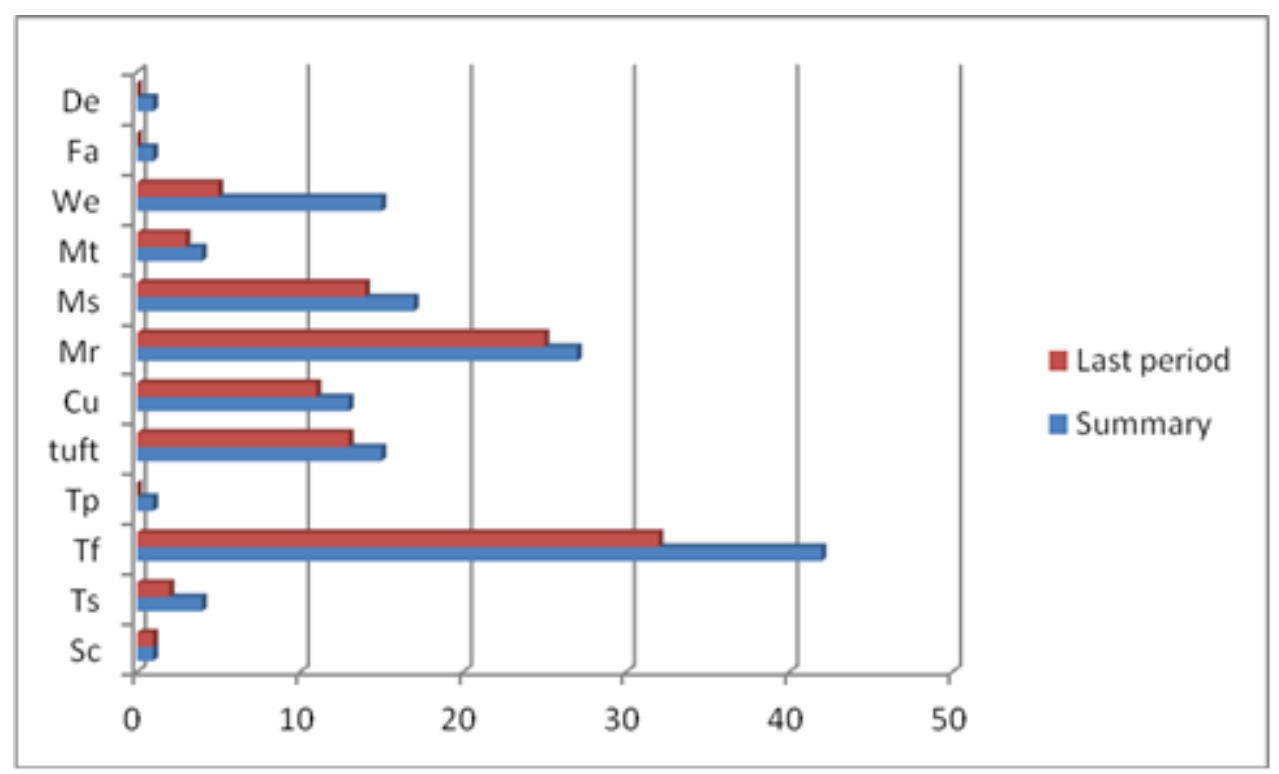

Fig. 2: The spectrum of life forms of bryophytes in Pohulyanka Forest Park: Sc (Solitary creeping), Tp (Turf protonemal), Ts (Turf scattered), Tf(Turf), tuft (Tuft), Cu (Cushion), De (Dendroid), Mr (Mat rough), Ms (Mat smooth), Mt (Mat thalloid), We (Weft), Fa (Fan). 
Certain patterns were observed in the distribution of bryophyte LFs depending on the type of substrate. In particular, bryophytes with the most common LF, turf (Tf), grow on all types of substrate and are most often found on bare soil, among grass plants, and on stony soil (33 species); in addition, 13 species were found on stony substrates, 5 species each were found on rotten wood and on phorophytes (epiphyte-bearing plants), and one species, Calliergon cordifolium, was found in an aquatic environment (Fig. 3).

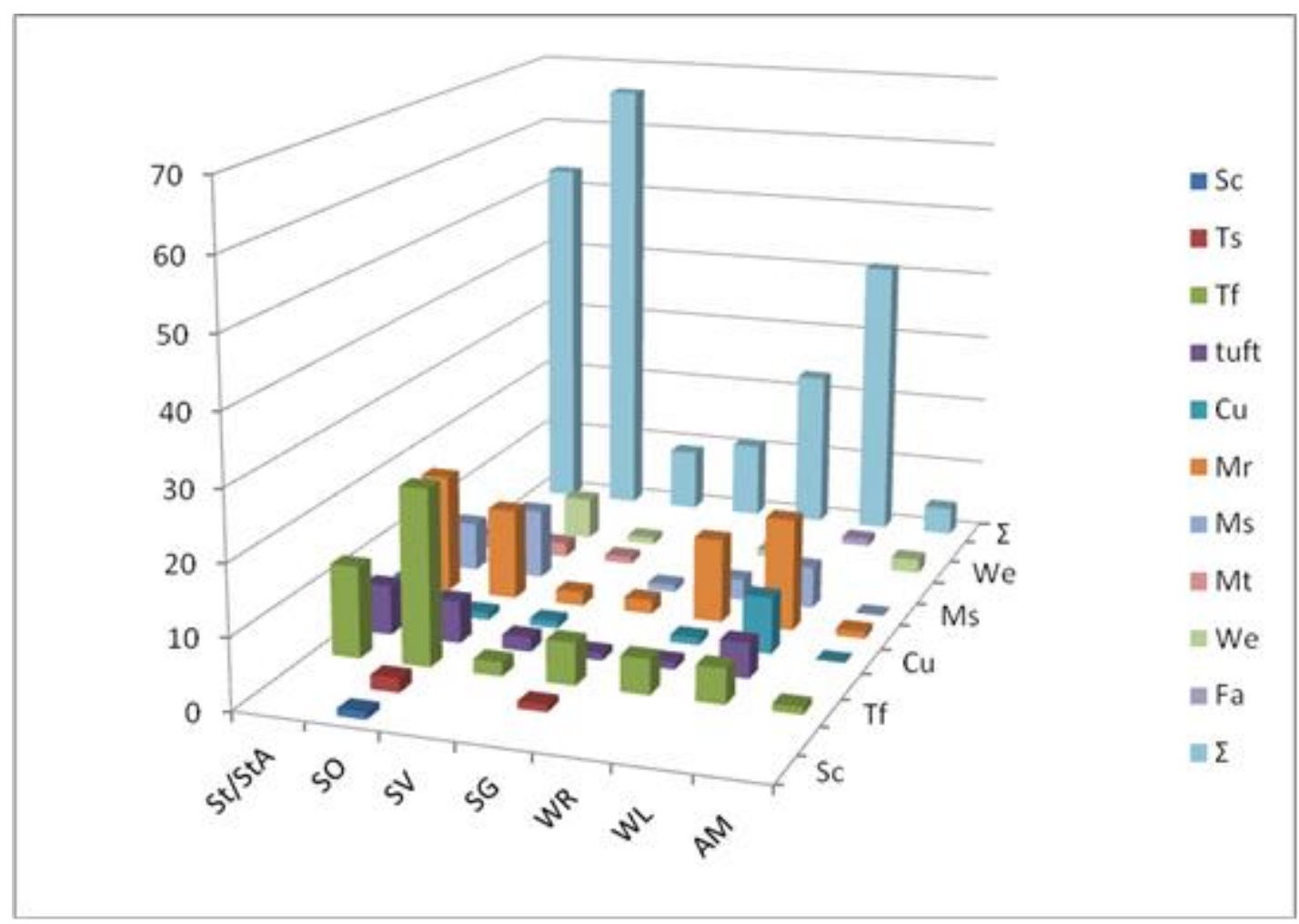

Fig. 3: Frequency of distribution of bryophyte life forms in the Pohulyanka Forest Park (identified during the last period) depending on the types of substrate ( $\mathrm{St}$ - stony; $\mathrm{StA}$ - stony artificial; SG - soil with gravel or sand; SO - soil; SV - on the soil among the grass plants or leaf litter; WR - rotten wood; WL - living wood; AM - aqueous medium).

With regard to the dependence of bryophyte LF on the anthropogenic impact, in particular on the mechanical load, the species with the LF weft were found to be the most sensitive (10 out of 15 species, or $67 \%$ have disappeared). This is due to the fact that they most often occur on the soil and, consequently, disappear because of trampling (namely, species of the genus Thuidium, Pleurozium schreberi, Hylocomium splendens, Pseudoscleropodium purum, Rhytidiadelphus triquetrus). Species with life forms such as turf protonemal (Ephemerum serratum) and dendroid (Climacium dendroides) have also disappeared. At the same time, the number of bryophytes with LF mat (primarily Mr) on the soil have increased, which can be explained by a high degree of adaptability, since they are more resistant to trampling than, for example, weft.

One of the manifestations of the anthropogenic transformation of bryoflora is its synanthropization, for the analysis of which the data on the species composition of bryophytes in the study area in previous periods are especially important. The results of our study show that indigenophytes (species that grow only in natural ecotopes or occur under conditions of minor 
anthropogenic interference) in the territory of the Pohulyanka Forest Park are presented by 20 species (14.2\%). Some species were found in the territory of the Botanical Garden, such as Aulacomnium palustre, Calliergon cordifolium, Leucodon sciuroides, Orthotrichum lyellii. Occurrence of some bryoflora species has not been confirmed by current findings. These are species such as the liverwort Lepidozia reptans, as well as Cirriphyllum piliferum, Dicranodontium denudatum, Herzogiella seligeri, Hylocomium splendens, Polytrichum piliferum, Thuidium assimile, Th. delicatulum and Th. recognitum.

Within the apophytic fraction of bryoflora, we have identified evapophytes (species that choose ecotopes modified by anthropogenic activities), hemiapophytes (growing in both natural and anthropogenically modified ecotopes), eventapophytes (more common in natural ecotopes than in anthropogenically modified ones), and spontaneophytes (species that occur by chance in anthropogenic ecosystems). The latter are usually difficult to distinguish from indigenophytes, therefore further detailed studies are needed. Evapophytes have not been identified in the study area; this is generally characteristic of the territory of Ukraine [4].

In general, the apophytic fraction of bryoflora in the study area contains 121 species (85.8\%) in 28 families, 66 genera, including 4 from the Marchantiophyta division. Representatives of the genera of Pottiaceae, Brachytheciaceae, Mniaceae, Orthotrichaceae and Bryaceae predominate here.

A small proportion of bryophyte species (20 species, $14.2 \%$ ) can be attributed to the group of spontaneophytes. These are species that grow in natural coenoses, and if they are found in anthropogenically modified ecotopes, the conditions are very close to natural due to minor anthropogenic interventions. The families Hypnaceae, Mniaceae and Polytrichaceae predominate among the spontaneophytes (Table 1).

Table 1: Indigenophyte and apophyte species in the leading families of bryoflora on the territory of the Pohulyanka Forest Park in Lviv.

\begin{tabular}{|c|c|c|c|c|c|}
\hline \multirow[t]{2}{*}{ Family } & \multirow{2}{*}{$\begin{array}{l}\text { Total number } \\
\text { of species } \\
\text { of the family }\end{array}$} & \multirow{2}{*}{$\begin{array}{l}\text { Number of } \\
\text { indigenophytes }\end{array}$} & \multicolumn{3}{|c|}{ Number of apophytes* } \\
\hline & & & $\mathrm{H}$ & $\mathrm{E}$ & $\mathrm{S}$ \\
\hline Brachytheciaceae Schimp. & 16 & 3 & - & 12 & 1 \\
\hline Pottiaceae Schimp. & 16 & - & 8 & 7 & 1 \\
\hline Mniaceae Schwägr. & 11 & - & - & 9 & 2 \\
\hline Orthotrichaceae Arn. & 10 & 1 & 4 & 5 & - \\
\hline Bryaceae Schwägr. & 9 & - & 6 & 3 & - \\
\hline Hypnaceae Schimp. & 9 & 1 & 1 & 4 & 3 \\
\hline Amblystegiaceae Kindb. & 8 & - & 4 & 3 & 1 \\
\hline Polytrichaceae Schwägr. & 7 & 0 & - & 5 & 2 \\
\hline Plagiotheciaceae (Broth.) Fleisch. & 7 & - & - & 6 & 1 \\
\hline Total & 93 & 5 & 23 & 54 & 11 \\
\hline
\end{tabular}

*Note: $\mathrm{H}$ - hemiapophytes, E - eventapophytes, $\mathrm{S}$ - spontaneophytes 
In the composition of bryoflora, 67 species of eventapophytes were recorded (47.5\% of the total number of species). The dominant families are Brachytheciaceae, Mniaceae, Pottiaceae, Plagiotheciaceae, Orthotrichaceae and Polytrichaceae. These are species such as representatives of the genera Plagiothecium, Orthotrichum, Plagiomnium and Brachythecium, which grow under conditions sufficiently close to natural ecotopes. A number of eventapophytes were found in the Pohulyanka Forest Park on various types of substrates. These include Brachytheciastrum velutinum, Brachythecium rutabulum, B. glareosum, B. salebrosum, Dicranum montanum, Hypnum cupressiforme, Oxyrrhynchium hians, Plagiomnium cuspidatum, Rhizomnium punctatum, Sciuro-hypnum populeum and other species [33].

Hemiapophytes comprised 34 species (24.1\% of the total number of species). The largest number of hemiapophytes was found in the families Pottiaceae, Bryaceae, Amblystegiaceae and Orthotrichaceae. This fraction is mainly represented by species that grow under conditions quite close to those of natural ecotopes: Plagiochila porelloides, Eurhynchium angustirete, Fissidens bryoides, Plagiothecium nemorale, P. cavifolium, Ptychostomum pseudotriquetrum, Rhynchostegium confertum and others.

In general, the 9 leading families comprise $73 \%$ of the apophytic fraction (Table 1), and the most dynamic in terms of apophytization are the Pottiaceae, Mniaceae, Bryaceae, Amblystegiaceae, and Plagiotheciaceae families, which are completely (100\%) represented by apophytic species. This is generally characteristic of synanthropic bryoflora of Ukraine [4]. Among the leading genera of bryoflora, indigenophytes are represented only in the genus Orthotrichum, and spontaneophytes are in Hypnum, Mnium, Plagiomnium, Plagiothecium, Polytrichum genera.

Bryoflora in the territory of the Pohulyanka Forest Park has some peculiarities of ecological structure. With regard to relationship to light, the following groups of bryophytes were identified in the study area: ultraheliophytes, heliophytes, subheliophytes, hemisciophytes, and sciophytes. The largest number of species was found in the groups of subheliophytes and hemisyophytes, which comprised $88 \%$ of the species composition found in recent decades (Fig. 4).

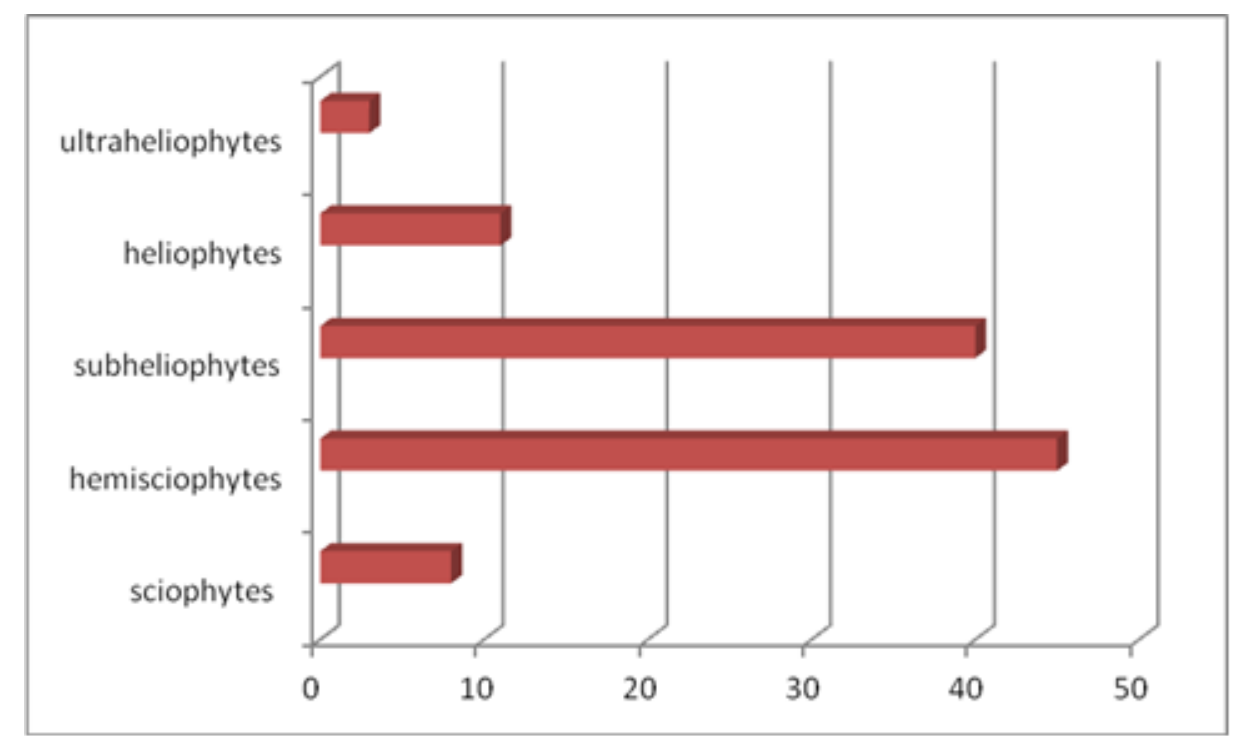

Fig. 4: Heliomorphs in the bryoflora of the Pohulyanka Forest Park in the city of Lviv.

We observed certain patterns in distribution of light-demanding species in groups of 
apophytes. Namely, the greatest number of heliophytes and subheliophytes was found among hemiapophytes and eventapophytes (Fig. 5). Ultraheliophytes prevailed in the hemiapophyte group. Hemisciophytes dominate in the groups of eventapophytes and spontaneophytes; they also dominate among indigenophytes, which reflects the ecological features of the bryophytes.

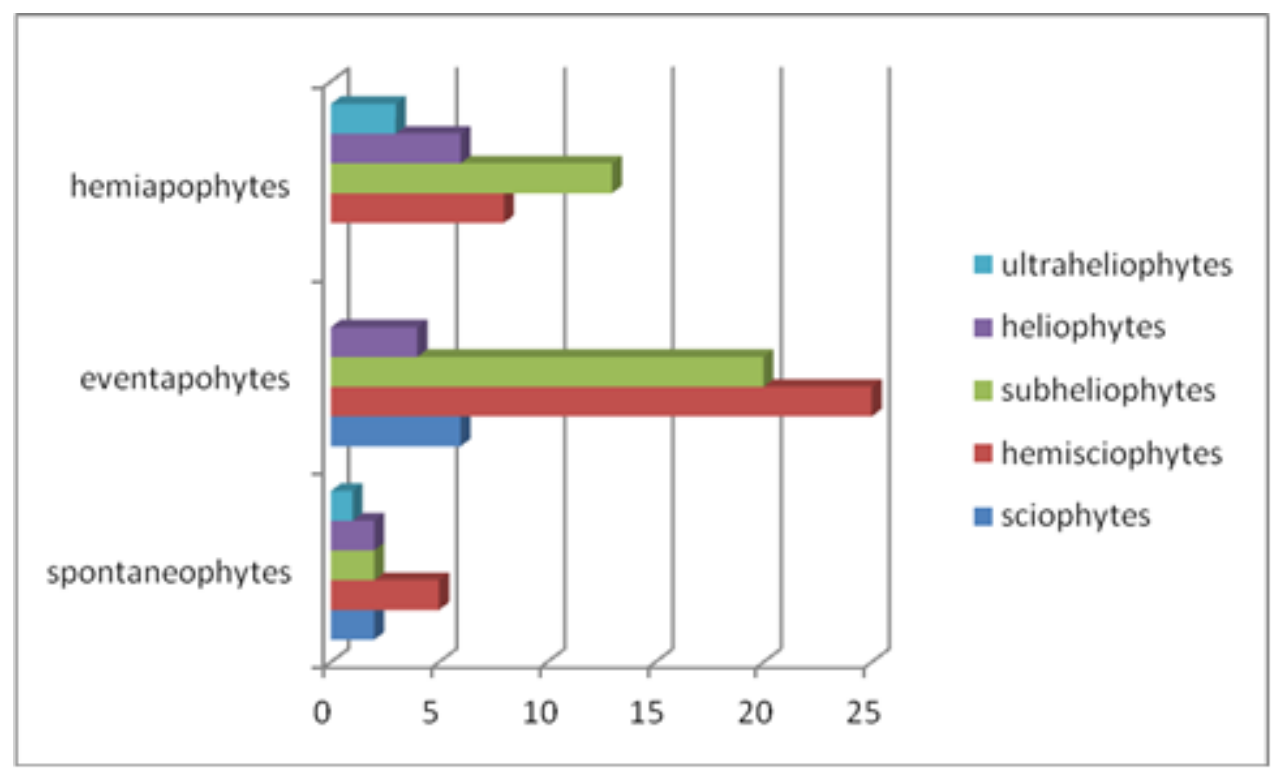

Fig. 5: Number of bryophyte species in the groups of apophytic fraction in the Pohulyanka Forest Park in relation to light.

Among hydromorphs in both fractions of bryoflora (natural and apophytic), the following groups were distinguished: ultraxerophytes $(1.9 \%)$, xerophytes $(6.5 \%)$, xeromesophytes $(27 \%)$, mesophytes (35.5\%), hygromesophytes (16\%), hygrophytes (10.3\%), hydrophytes (2.8\%) (Fig. 6).

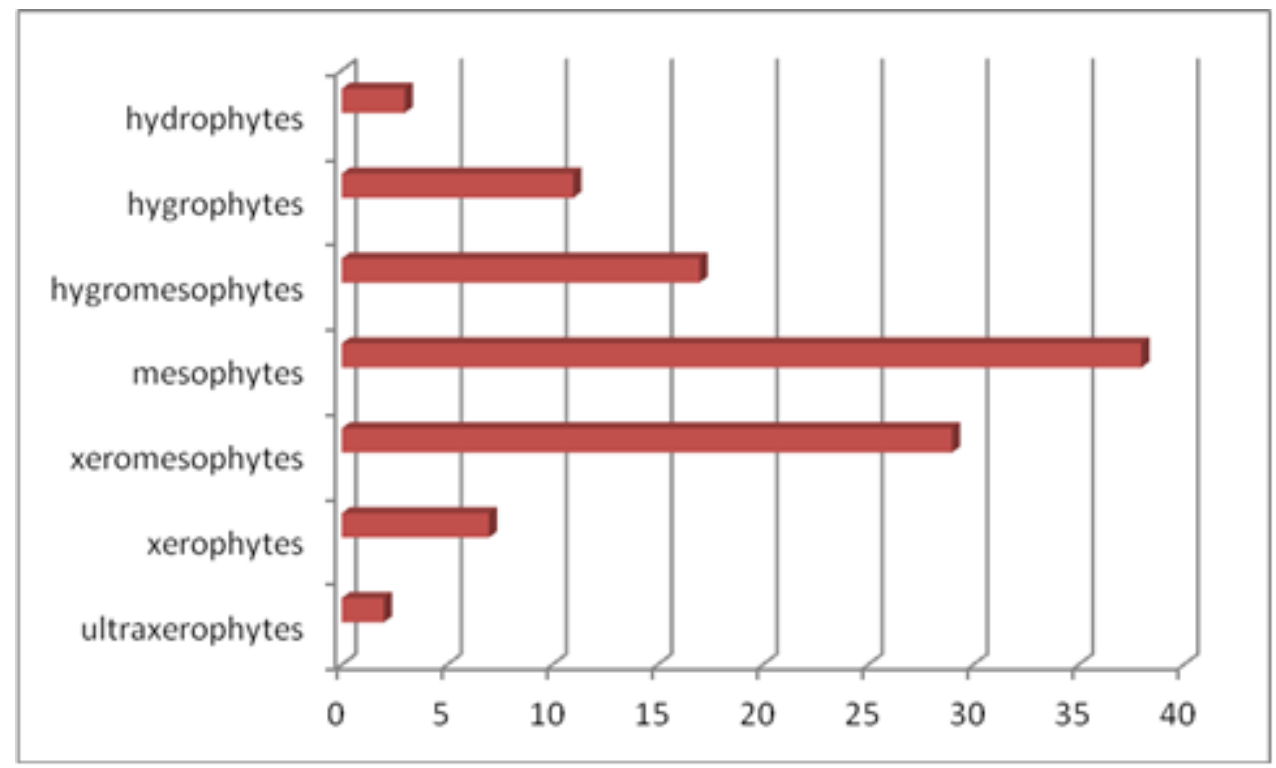

Fig. 6: Hydromorphs in the bryoflora of the Pohulyanka Forest Park. 
Neither xerophytes nor ultraxerophytes were found in the natural fraction, but all hydromorph groups were represented in the apophytic fraction. Species adapted to dry conditions prevailed among hemiapophytes; they were found in the group of eventapophytes, but were absent from the spontaneophyte group (Fig. 7).

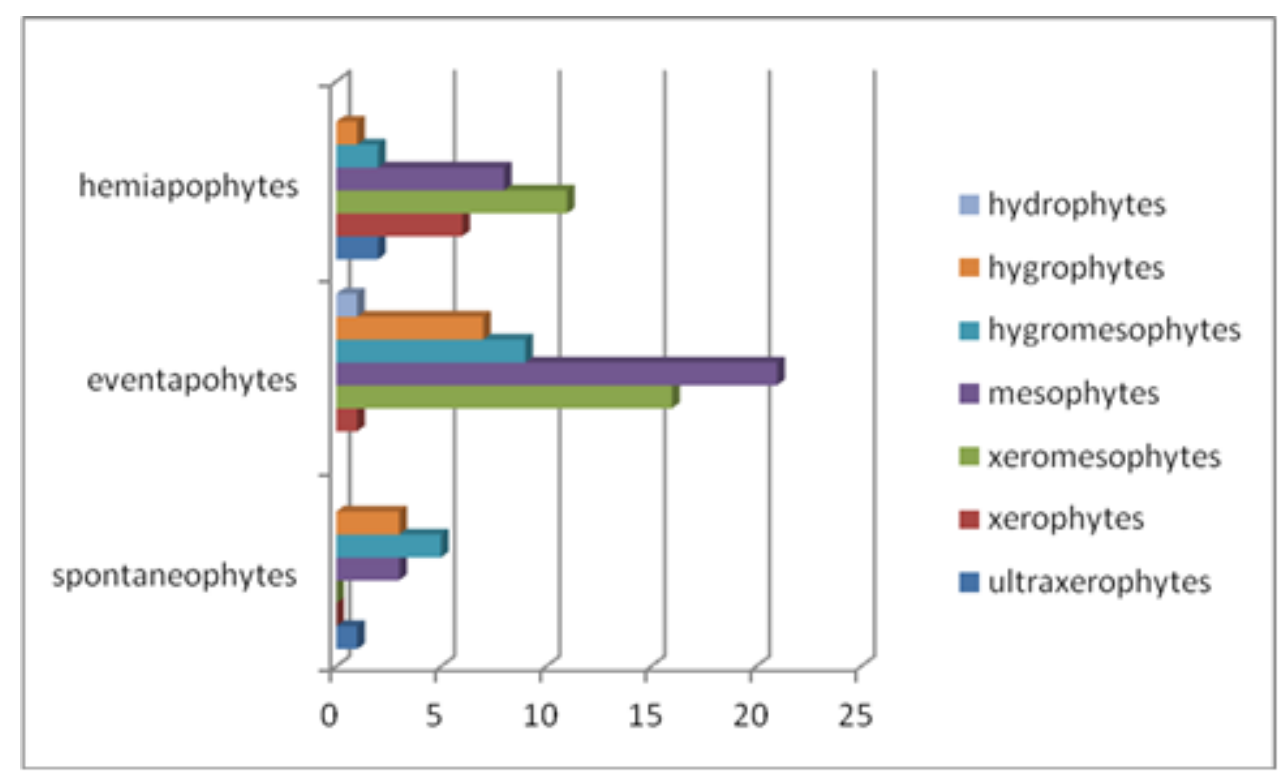

Fig. 7: The number of bryophyte species in the groups of apophytic fraction of the Pohulyanka Forest Park with respect to the moisture content in the substrate

\section{Discussion}

In general, the bryoflora of the Pohulyanka Forest Park is characterized by taxonomic and ecological diversity. The variety of mosses differs significantly between different parts of the study area. Species diversity is most pronounced in the adjacent territory of the Botanical Garden, as well as on the slopes of the springs. The minimum species diversity is observed in places of intensive recreational activity, although some species of mosses are found there on various substrates, including artificial ones. Of particular note is a type of substrate such as rotten wood (WR), which is very rare due to the cleaning of the park. Since decayed wood is less suitable for vascular plant growth than other substrates, bryophytes are not under competitive pressure; furthermore, rotten wood retains more moisture, which contributes to the growth of mosses on this substrate. On rotten wood, successional changes from epiphytic-epixylic to epigeic species can be observed.

The species and ecological diversity of urban bryoflora depends on the degree of influence of anthropogenic factors [2, 27, 45]. Within cities, the parks and forest parks possess the greatest wealth of bryoflora, which is associated with a large variety of ecotopes, substrates, higher humidity and less anthropogenic impact [3, 36, 53-55, 58]. Pohulyanka Forest Park is characterized by favourable conditions for the development of bryophytes, which grow exclusively in natural or very slightly modified ecotopes. In recent years, species of indigenophytes have been identified among Marchantiophyta (Cephalozia bicuspidata, Plagiochila porelloides), and among Bryophyta (Diphyscium foliosum, Homalia trichomanoides, Eurhynchium angustirete, Fissidens exilis, Aulacomnium palustre, Leucodon sciuroidesa and Orthotrichum lyellii). 
For the bryoflora of many European cities, a small percentage of liverworts is inherent; this is also characteristic of parks, arboreta and botanical gardens [27, 41, 50, 55].

Favourable microclimate (humidity, certain substrates, low degree of trampling, etc.) even in anthropogenic ecotopes, favours the development of urban-tolerant species, such as Brachythecium rutabulum, Grimmia pulvinata, Orthotrichum diaphanum, Bryum capillare, B. argenteum, Tortula muralis, Rhynchostegium confertum, Hypnum cupressiforme and Amblystegium serpens [21]; in addition, species such as Tortula muralis, Bryum argenteum, B. capillare, Funaria hygrometrica, and Schistidium apocarpum settle on artificial substrates and even sometimes in areas with significant anthropogenic load.

In recent decades, urban areas of Europe have seen an increase in the rates of colonization of phorophytes and stony substrates by urbanophilic and urban-tolerant bryophyte species $[15,31$, 36], which are also common in the urban ecosystem of the city of Lviv, including in the territory of the Pohulyanka Forest Park. The main features of such species are xerophytism and mesophytism, resistance to pollution, as well as the prevalence of life forms of cushions, turfs and rough mats.

The predominance of xerophytes [3] and loss of moisture-loving species is peculiar to the urban bryoflora [52]. An analysis of the distribution of life forms demonstrates the dominance of turfs (Didymodon, Philonotis, Ptychostomum and Tortula) and mats (Brachythecium, Hypnum), and distribution of cushions (for example, Grimmia and Orthotrichum species) on drier places, which coincides with the results of other studies [1,27].

At the same time, in ecotopes exposed to a strong anthropogenic load, for example, in central densely populated areas of the city of Lviv or in the vicinity of railway lines, hemiapophytes prevail over eventapophytes. In particular, the results of our recent studies show that hemiapophytes make up 52.6\% and $66.7 \%$, respectively, near the railways and in the central part of Lviv [32-35, 56]. The most common hemiapophytes are Marchantia polymorpha, Amblystegium serpens, Barbula unguiculata, Bryum argenteum, B. caespiticium, Ceratodon purpureus, Didymodon rigidulus, Funaria hygrometrica, Grimmia pulvinata, Hygroamblystegium varium, Leskea polycarpa, Platygyrium repens, Ptychostomum moravicum, Pylaisia polyantha, Syntrichia ruralis, Tortula muralis, and Orthotrichum spp.

Thus, parks and forest parks in urban ecosystems are characterized by a significant diversity of bryophytes. These plants have occupied their ecological niche and not only become a significant addition to the phototrophic complex, but also perform an important function in increasing biodiversity and creating conditions for the colonization of these territories by other biota.

\section{REFERENCES}

1. Aleffi, M., 2017, Contribution to the knowledge of the Bryophyte Flora of the Vatican City State: The Pontifical Villas of Castel Gandolfo, Flora Mediterranea, 27: 137-150.

2. Barsukov, O.O., 2014, Bryoflora of urban territories of Kharkiv oblast, Chornomorski Botanical Journal, 10 (3): 305-321.

3. Barsukov, O.O., Jarotsky, V. JU., 2009, Bryophytes of green plantations of Kharkiv city, Forestry \& Forest Melioration, 116: 250-259.

4. Boiko, M.F., 2005, Synantropic bryoflora of Ukraine, Chornomorski Botanical Journal, 1 (2): 24-32. 
5. Boiko, M.F., 2014, The Second checklist of Bryobionta of Ukraine, Chornomorski Botanical Journal, 10 (4): 426-487.

6. Cristea, V., Gafta, D., Baciu, C., Goia, I., Drăguţ, L., Coroiu, I., 2003, Multidisciplinary assesssment of the landscape development around the Cluj-Napoca city (Romania), Multifunctional Landscapes, II, Monitoring, Diversity and Management: 271-285.

7. Dierßen, K., 2001, Distribution, ecological amplitude and phytosociological characterization of European bryophytes, Bryophytorum Bibliotheca, 56: 1-289.

8. Didukh, Ya., Plyuta, P., Protopopova, V., Ermolenko, V., Korotchenko, I., Karkutsiev, G., Burda, R., 2000, Ecoflora of Ukraine Vol. 1. Kyiv, Phytosociocentre: 58-59.

9. Düll, R., 1991, Indicator values of mosses and liverworts - Ellenberg H. ao. Indicator values of plants in Central Europe, Göttingen, Erich Goltze: 175-214.

10. Fojcik, B., Chruścińska, M., Nadgórska-Socha, A., Stebel, A., 2015, Determinants of occurrence of epiphytic mosses in the urban environment; a case study from Katowice city (S Poland), Acta Musei Silesiae, Scientiae Naturales, 64: 275-286.

11. Fudali, E., 1996a, Distribution of bryophytes in various urban-use complexes of Szczecin [NW Poland], Fragmenta Floristica et Geobotanica, 41 (2): 717-745.

12. Fudali, E., 1996b, The bryoflora of Szczecin: I. Bryophytes of the city, Fragmenta Floristica et Geobotanica. Seria Polonica, 3: 103-116.

13. Fudali, E., 2006, Influence of city on the floristical and ecological diversity of bryophytes in parks and cemeteries, Biodiversit. Research and Conservation, 1-2: 131-137.

14. Fudali, E., 2011, Zmiany zachodzące współcześnie w brioflorze miast - na przykładzie parków Wrocławia (obserwacje $z$ lat 2000, 2006 i 2011) (Contemporary changes in urban bryophytes; a case study of Wrocław parks carried out in 2000, 2006 and 2011), Acta Botanica Silesiaca, 6: 81-95.

15. Fudali, E., 2012, Recent tendencies in distribution of epiphytic bryophytes in urban areas: a Wrocław case study (southwest Poland), Polish Botanical Journal, 57: 231-241.

16. Gapon, Yu V., 2016, The list of bryophytes of Poltava city and its surroundings, Biology \& Ecology, 2 (2): 4050.

17. Goia, I., 2002, Briofitele. In: Cristea, V., Baciu, C., Gafta, D., (eds.), Municipiul Cluj-Napoca şi zona periurbană. Studii ambientale. Ed. Accent, Cluj-Napoca: 111-122.

18. Goia, I., Danci, O., 2006, Epyphytic bryophytes as bioindicators of air quality in Baia Mare city (Romania), Environment \& Progress, 6: 204-209.

19. Goia, I., Şut, C., Danci, O., Niculescu, M., 2005, Bryophytes as bioindicators of air and soil quality in Baia Mare City (Romania), Revue de Cytologie et Biologie végétales-Le Botaniste, 28: 307 - 314

20. Golubets, M.A., Kozak, I.I., 1994, The main features of the digression of biogeocoenotic cover in the Carpatians region. In: Golubets M.A. et all., Antropogenic changes of the biogeocoenotic cover in the Carpatians region, Naukova Dumka, Kyiv.

21. Govindapyari, H., Leleeka, M., Nivedita, M., Uniyal, P.L., 2010, Bryophytes: indicators and monitoring agents of pollution, $\mathrm{NeBIO}, \mathbf{1}(1)$ : $35-41$.

22. Hill, M.O., Preston, C.D., Bosanquet, S.D.S., Roy, D.B., 2007, BRYOATT: Attributes of British and Irish mosses, liverworts, and hornworts - NFRC Centre for Ecology and Hydrology and Countryside Council for Wales, Saxon Print Group, Norwich.

23. Isermann, M., 2007, Diversity of bryophytes in an urban area of NW Germany, Lindbergia, 32 (3): 75-81.

24. Kornaś, J., 1968, A geographical-historical classification of synanthropic plants, Materialy Zakladu Fitosocjologii Stosowanej Uniw. Warszawskiego, 25: 33-41.

25. Lilienfeldówna, F., 1910, Hepaticae Poloniae exiccate, Kosmos, 35: 732-738.

26. Lilienfeldówna, F., 1914, Hepaticae Poloniae exiccate, Sprawozdaniekomisyi flzyograficznej, 48: 51-58.

27. Lo Giudice, R., Mazimpaka, V., F., Lara, 1997, The urban bryophyte flora of the city of Enna (Sicily, Italy), Nova Hedwigia, 64: 249-265.

28. Mamchur, Z.I., 2003, Antropogenic transformation of the epiphytic bryoflora of Lviv city and surroundings, Visnyk of L'viv University. Biological Series, 34: 135-141.

29. Mamchur, Z.I., 2004, Distribution of epiphytic mosses in urban environment, Visnyk of L'viv University. Biological Series, 36: 70-77. 
30. Mamchur, Z.I., 2010, Urbanophilic epiphytic mosses of Lviv city, Visnyk of L'viv University. Biological Series, 54: $115-122$.

31. Mamchur, Z., Bilska, I., 2013, Epiphytic bryophytes features in urban environment, Visnyk of L'viv University. Biological Series, 61: 125-132.

32. Mamchur, Z.I., Chuba, M.V., 2016, The ecological features of synanthropic flora of dense housing area of Lviv, Studia Biologica, 10 (1): 143-154.

33. Mamchur, Z.I., Drach, Yu.A., Danylkiv, I.S., 2018, Bryoflora of the "Pohulyanka" forest park (Lviv city). Changes in taxonomic composition under antropogenic transformation, Studia Biologica, 12 (1): 99-112.

34. Mamchur, Z.I., Chuba, M.V., Drach, Yu.A., 2017a, Mosses and vascular plants on railway tracks in the Lviv city, Visnyk of L'viv University. Biological Series, 75: 54-65.

35. Mamchur, Z., Chuba, M.V., Drach, Yu.A., 2017b, The ecological features of plants of railway in the Lviv city, Studia Biologica 11 (1): 135-146.

36. Marka, J., Zaloshnja, I., 2017, Epiphytic mosses in the centre of Tirana city (Albania), Studia botanica hungarica, 48 (1): 51-65.

37. Maslovsky, O.M., 2012, Synanthropic bryoflora of Belarus, Chornomorski Botanical Journal, 8 (2): 205-213.

38. Ochyra, R., 1983, Mszaki synantropijne, Wiadomosci botaniczne, 27 (1): 31-44.

39. Pokorny, L., Lara, F., Mazimpaka, V., 2006, The bryophyte flora of the city of Trento (North Italy), Cryptogamie Bryologie, 27 (2): 265-284.

40. Protopopova, V.V., 1991, Synantropic flora of Ukraine and its development. Kiev. Nauk. Dumka.

41. Sabovljevic, M., Grdovic, S., 2009, Bryophyte diversity within urban areas: case study of the city of Belgrade (Serbia), International Journal of Botany, 5 (1): 85-92.

42. Schaepe, A., 1986, Veranderungen der Moosflora von Berlin (West), Bryophytorum Bibliotheca, 33: 1-392.

43. Scherbachenko, O., Rabyk, I., 2004, Bryophytes of the side zone of Lviv reservoirs, Proceedings of the State Museum of Natural History, 19: 39-46.

44. Shabliy, O., 2012, Natural-geographical position of the city Lviv: the physical and geographical position of the city in Europe. In: Shabliy, O., Lviv: comprehensive atlas, SSPE "Cartography”, Kyiv.

45. Skudnik, M., Sabovljević, A., Batič, F., Sabovljević, M., 2013, The bryophyte diversity of Ljubljana (Slovenia), Polish Botanical Journal, $\mathbf{5 8}$ (1): 319-324.

46. Soria, A., Ron, M., 1995, Aportaciones al conocimiento de la brioflora urbana espacola, Cryptogamie. Bryologie, lichénologie, 16 (4): 285-299.

47. Soria, A., Ron, M., 1990, Datos para el conocimiento de la flora briológica urbana de la ciudad de Logrońo, Anales Jard. Bot. Madrid, 46 (2): 427-432.

48. Stebel, A., Fojcik, B., 2016, Changes in the Epiphytic Bryophyte Flora in Katowice City (Poland), Cryptogamie, Bryologie, 37 (4): 399-414.

49. Sukopp, H., Werner, P., 1983, Urban environments and vegetation. Man's impact on vegetation, Haque; Bostonn, London: 247-260.

50. Szücs, P., 2017, Bryophyte flora of the Botanic Garden of the University of Sopron (W Hungary), Studia Botanica Hungarica, 48 (1): 77-88.

51. Vanderpoorten, A., 1997, A bryological survey of the Brussels capital region (Belgium), Scripta Botanica Belgica, 14: 1-40.

52. Virchenko, V.M., 1991, Changes in the bryoflora of the Darnitsky Forest Park (Kyiv) over the past 100 years, Ukrainian Botanical Journal, 48 (1): 44-49.

53. Virchenko, V.M., 2006, Bryophytes of the forest-park zone of Kyiv, Znannya Ukrainy, Kyiv.

54. Virchenko, V.M., Pryadko, O.I., Onyshchenko, V.A., 2016, Vascular plants and bryophytes of Holosiivskyi national nature park, Alterpress, Kyiv.

55. Wolski, G.J., Stefaniak, A., Kowalkiewicz, B., 2012, Bryophytes of the experimental and teaching garden of the faculty of biology and environmental protection, university of Lodz (Poland), Ukrainian Botanical Journal, 69 (4): 519-529.

56. Wrzesień, M., Denisow, B., Mamchur, Z., Chuba, M., Resler, I., 2016, Composition and structure of the flora in intra-urban railway areas, Acta Agrobotanica, 69 (3): 1666.

57. Zanten, B.O., Kruijer, H., 2012, Bryophytes of botanical garden 'De Wolf', Haren (Groningen), Buxbaumiella, 91: $20-33$ 
58. Zechmeister, H.G., Tribsch, A., Hohenwallner, D., 2002, Die Moosflora von Linz und ihre Bedeutung für die Bioindikation, Naturkundliches Jahrbuch der Stadt Linz, 48: 111-191.

\section{CARACTERISTICI ECOLOGICE ȘI SINANTROPIZAREA BRIOFLOREI DIN PĂDUREA PARC POHULYANKA (ORAȘUL LVIV, UCRAINA)}

\section{(Rezumat)}

Lucrarea de față analizează caracteristicile ecologice ale speciilor de briofite de pe teritoriul Pădurii Parc Pohulyanka din orașul Lviv, Ucraina. Au fost analizate 141 specii de briofite, dintre care 70 menționate pentru prima dată. În ceea ce privește spectrul bioformelor, au predominat speciile in tufe dense TURF (61 specii, 43.3\%) și cele târâtoare, aderente la substrat.MAT (48 specii, 34\%). Speciile în tufe dense TURF, cea mai comună bioformă, a fost întâlnită pe toate tipurile de substrat, dar mai frecvent pe sol (33 specii, 23.4\%) și substrat stâncos (13 specii, 9.2\%). Analiza specimenelor de herbar (herbariile Universităţii Ivan FranKo din Lviv, ale Muzeului Naţional de Istorie Naturală și Academiei Naţionale de Ştiințe din Ucraina) și rezultatele obținute cu privire la compoziţia brioflorei sugerează că, datorită transformării antropogenice a zonei studiate, majoritatea speciilor cu bioformă de tip împletire laxă WEFT (10 din 15 specii, sau 66.7\%) au dispărut, în timp ce a crescut numărul speciilor cu bioformă de tip covoraşe rugoase ROUGH MAT pe suprafața solului. Mușchii de tip apofitic au fost reprezentați de 121 specii (85.8\%) aparținând la 28 familii și 66 genuri, inclusiv patru specii din diviziunea Marchantiophyta. În compoziția brioflorei au fost identificate 67 specii ocazionale (eventapofite) (47.5\% din totalul speciilor). Familiile dominante sunt Brachytheciaceae, Mniaceae, Pottiaceae, Plagiotheciaceae, Orthotrichaceae, Polytrichaceae. Hemiapofitele reprezintă 24.1\% (34 specii) din total. Cel mai mare număr de hemiapofite au aparținut familiilor Pottiaceae, Bryaceae, Amblystegiaceae și Orthotrichaceae. Dintre spontaneofite (20 specii, 14.2\%), majoritatea au aparținut familiilor Hypnaceae, Mniaceae și Polytrichaceae. Indigenofitele au fost reprezentate de 20 de specii (14.2\%). În ceea ce privește dependența briofitelor de lumină, au fost identificate următoarele grupe: ultraheliofite, heliofite, subheliofite, hemisciofite și sciofite. Cele mai multe specii au fost subheliofite şi hemisciofite. Anumite tipare s-au întâlnit în raportul speciilor iubitoare de soare din grupul apofitelor. În cadrul speciilor hidromorfe, s-au identificat următoarele grupe: ultraxerofite (exclusiv dintre hemiapofite), xerofite (dominante în grupul hemiapofitelor, dar întâlnite și între eventapofite), xeromezofite, mezofite, higromezofite şi higrofite (prezente în toate grupele antropotolerante), hidrofite (event- şi spontan/indigenofite). 